\title{
Body Substance Contamination
}

National Cancer Institute

\section{Source}

National Cancer Institute. Body Substance Contamination. NCI Thesaurus. Code C87024.

An artifact resulting from the contamination of the imaging field with an extraneous body substance. 